\title{
A comparative study between nifedipine and isoxsuprine in the suppression of preterm labor pain
}

\author{
Susheela Khoiwal, Vandana Patidar*, Radha Rastogi, Bharat Tailor
}

Department of Obstetrics and Gynecology, RNT Medical College, Udaipur, Rajasthan, India

Received: 02 May 2020

Accepted: 30 May 2020

\section{*Correspondence:}

Dr. Vandana Patidar,

E-mail: sandeepbapna1971@gmail.com

Copyright: (C) the author(s), publisher and licensee Medip Academy. This is an open-access article distributed under the terms of the Creative Commons Attribution Non-Commercial License, which permits unrestricted non-commercial use, distribution, and reproduction in any medium, provided the original work is properly cited.

\begin{abstract}
Background: A prospective study was conducted to compare the effectiveness of Nifedipine and Isoxsuprine in suppression of preterm labour pain as tocolytics drug. As preterm labour pain is major contributor for perinatal morbidity and mortality. The aims of this study were to assess the effect of nifedipine and isoxsuprine in threatened preterm labour with the aim of preventing preterm birth and its sequelae.

Methods: This study was conducted on 100 patients coming to Pannadhay Rajkiya Mahila Chikitsalaya, RNT Medical College, Udaipur and attending OPD and IPD with complain of uterine contractions between 28-36 weeks of gestation.

Results: Nifedipine was more effective than isoxsuprine hydrochloride as tocolytic agent.

Conclusions: There is high incidence of preterm labour in India which leads to neonatal morbidity and mortality. Nifedipine is a better tocolytic drug compared to isoxsuprine hydrochloride.
\end{abstract}

Keywords: Isoxsuprine, Nifedipine, Preterm labor pain, Tocolytic drug

\section{INTRODUCTION}

Preterm labour remains one of the unbeaten frontiers in present era of obstetrics, despite improvements in obstetric care in past three decades, incidence of preterm labour has actually increased in recent years. Preterm delivery affects $11 \%$ in U.S. or even greater in developing countries (23.3\% in India). ${ }^{1,2}$

The global annual incidence of preterm birth in 2005 was reported by WHO world health organization to be $9.6 \%$ of all live births. ${ }^{3}$ Factors contributing to increasing incidence of preterm births include increasing rates of multiple births, psychosocial stress, medically induced prematurity greater use of assisted reproduction techniques, and increase in proportion of births among older women ( $>35$ years of age). According to WHO, in $2010,40 \%$ of all under-five deaths (>3 million deaths) occurred during the first month of life with prematurity contributed to nearly one -third of these deaths. $12 \%$ of child mortality under 5 years of age are due to complications of prematurity; making it one of the four major killers of this age group. ${ }^{4}$ Preterm birth, defined by WHO as the onset of labour prior to the completion of 37 weeks of gestation, in a pregnancy beyond 20 weeks of gestation. ${ }^{5}$ Prediction and prevention of preterm labor is not possible despite extensive research on the subject, therefore therapy cannot be directed to specific cause. Authors have to face preterm labor and manage this study patients according to their gestational age. A variety of agents have been advocated for suppressing uterine contractions. There is no clear evidence that tocolytic agents improve outcome and therefore it is reasonable to not to use them. However, tocolysis should be considered if few days gained would be used for completing a course of corticosteroids which will help in lung maturity thereby preventing respiratory distress syndrome in the new-born if delivery occurs within 7 days of steroid 
administration or in utero transfer to higher medical centre where adequate NICU facilities can be provided to the neonate as and when required. ${ }^{6,7}$ Preterm labor before 34 weeks needs to be arrested for at least 48 hours so that fetal pulmonary maturity is attained using betamethasone coverage. Delivery between 34 and 37 weeks reduces the risk of respiratory distress syndrome but does not exempt the baby from other complications of prematurity. Thus, tocolytic agents are frequently used in obstetric practice. $\beta$-adrenergic receptor blocking agent isoxsuprine hydrochloride and calcium channel blocker nifedipine are two commonly used tocolytic agent in India. Nifedipine is a calcium channel blocker. It works by affecting the movement of calcium into the cells of the heart and blood vessels. As a result, nifedipine relaxes blood vessels and increases the supply of blood and oxygen to the heart while reducing its workload. Isoxsuprine hydrochloride is a beta-adrenergic agonist that causes direct relaxation of uterine and vascular smooth muscle. Its vasodilating actions are greater on the arteries supplying skeletal muscle than on those supplying skin. Efforts are directed towards finding alternatives that are safer, better tolerated, as well as efficacious in prolonging pregnancy. ${ }^{8}$ Both nifedipine and isoxsuprine have been shown to be effective in preterm labour. However only a few studies have directly compared the safety and efficacy of nifedipine with isoxsuprine as tocolytic in preterm labour. ${ }^{9}$ In this study, authors compare the safety and efficacy of nifedipine with isoxsuprine as tocolytic in women with preterm labour.

This study was done to compare their efficacy and analyse the overall outcome of preterm labor using tocolytics in authors college PDZH, Udaipur Rajasthan, India.

\section{Aims and objectives}

- To compare the tocolytic efficacy of nifedipine and isoxsuprine in the suppression of preterm labour.

- To evaluate the maternal side effects and neonatal outcome of the two drugs.

\section{METHODS}

This was a prospective study of 64 antenatal women conducted in the department of obstetrics and Gynecology, RNT Medical college Udaipur. Written informed consent was taken from the patients included in this study. Antenatal women between 28 to 36 weeks of gestation with painful intermittent contractions are considered for study. They were evaluated thoroughly by detailed history, clinical examination and USG if not done before. Amniotic membrane status was noted in vaginal examination.

\section{Inclusion criteria}

- Gestational age between 28 to 37 weeks
- Presence of regular uterine contractions 4 in 20 minutes or 8 in a period of 1 hour

- Cervical changes - cervical effacement $>80 \%$ or dilatation of $>1 \mathrm{~cm}$ with intact membranes

- No previous administration of tocolytics.

\section{Exclusion criteria}

- Systemic diseases like diabetes mellitus, cardiac diseases, liver or renal diseases, hypotension

- Obstetric complications like hypertensive disorders of pregnancy, antepartum haemorrhage, ruptured membranes, dilatation of $>4 \mathrm{~cm}$

- Foetal complications like chorioamnionitis, IUGR, congenital anomaly, foetal distress

- Multifoetal gestation.

Patients will be monitored from the time of admission to the time of discharge.

Group I constituted subjects who were given $20 \mathrm{mg}$ oral nifedipine initially followed by $10 \mathrm{mg}$ at 4 hourly intervals for 48 hours. Drug dose was gradually tapered every 24 hours and then stopped. If contractions persisted at $90 \mathrm{~min}$, the first $10 \mathrm{mg}$ dose was started at the same time.

Group II constituted subjects who were given injection isoxsuprine $10 \mathrm{mg}$ intramuscularly and repeated at 6 hours interval for $48 \mathrm{~h}$. Patients who responded were switched over to $20 \mathrm{mg}$ oral retard tablet given 12 hourly as maintenance therapy for 1 week. In both groups subjects were strictly monitored for uterine contractions, maternal pulse rate, palpitation and fetal heart rate. In case of any serious side effects as progression of labor, the respective drug was stopped.

All women with preterm labor were investigated for infection by complete hemogram, urine and vaginal swab culture. Antibiotics were provided to cases having significant pathogen count in urine or vaginal culture accordingly. Women with gestational age less than 34 completed weeks were given $12 \mathrm{mg}$ betamethasone intramuscularly that was repeated after an interval of 24 hours. Goal of tocolysis was to delay delivery for 48 hours in patients with ruptured membranes and through 36 completed weeks of gestation in patients with intact membranes. Tocolysis was considered failed if uterine quiescence was not achieved despite maximum dose and delivery occurred within 48 hours. Patients, in whom delivery was delayed for at least 48 hours, were taken as cases of primary success. Patients were followed till delivery and data was recorded about side effects that patients developed during the treatment, time interval between admission and delivery and neonatal outcome.

\section{Statistical analysis}

Statistical analysis was done using SPSS 1. 


\section{RESULTS}

Out of 64 women with singleton pregnancies who enrolled for study, 32 were assigned to isoxsuprine group and 32 to nifedipine group after randomization. In this study, patients distributed according to gestational age, majority of patients were between 28 to 32 weeks of gestation $(62.3 \%$ versus $68.75 \%)$ in nifedipine group and isoxsuprine group respectively as shown in Table 1. There is no significant difference in gestational age in both study groups.

Table 1: Distribution of preterm labor cases according to gestational age $(n=64)$.

\begin{tabular}{|c|c|c|c|c|}
\hline \multirow[t]{2}{*}{$\begin{array}{l}\text { Gestational } \\
\text { age }\end{array}$} & \multicolumn{2}{|c|}{$\begin{array}{l}\text { Group } 1 \\
\text { nifedipine } \\
\text { group }(n=32)\end{array}$} & \multicolumn{2}{|c|}{$\begin{array}{l}\text { Group } 2 \\
\text { isoxsuprine } \\
\text { group }(n=32)\end{array}$} \\
\hline & No. & $\%$ & No. & $\%$ \\
\hline 28-30 weeks & 9 & 29 & 8 & 25 \\
\hline 31-32 weeks & 11 & 34.33 & 14 & 43.75 \\
\hline 33-36 weeks & 12 & 36.67 & 10 & 31.25 \\
\hline
\end{tabular}

Table 2: Maternal factors in both treatments group.

\begin{tabular}{|lll|}
\hline & $\begin{array}{l}\text { Group 1 } \\
\text { nifedipine } \\
\text { group }(\mathbf{n = 3 2})\end{array}$ & $\begin{array}{l}\text { Group 2 } \\
\text { isoxsuprine } \\
\text { group }(\mathbf{n}=32)\end{array}$ \\
\hline Parity & & 12 \\
\hline Primi (n) & 17 & 20 \\
\hline Multi (n) & 15 & 25.4 \\
\hline Mean age (years) & 24.2 & \\
\hline
\end{tabular}

In this study, primigravidae were more in nifedipine group (53.12\%) as compared to isoxsuprine group $(34.28 \%)$ as shown in Table 2. There was no significant difference between two groups.

Table 3 shows final outcome of the two types of tocolysis used in present study. Overall success rate achieved in nifedipine group was $84.37 \%$ while in isoxsuprine group was $71.87 \%$, which shows significant benefit in Nifedipine group. Failure rate was $28.87 \%$ in isoxsuprine group compared to $15.62 \%$ in nifedipine group which was quite significant different.

Table 3: Comparative effect of tocolysic therapy in two groups.

\begin{tabular}{|c|c|c|c|}
\hline Admission delivery interval & $\begin{array}{l}\text { Group } 1 \text { nifedipine group } \\
(\mathrm{n}=32)\end{array}$ & $\begin{array}{l}\text { Group } 2 \text { isoxsuprine } \\
\text { group }(\mathbf{n = 3 2})\end{array}$ & Total $(n=64)$ \\
\hline$<48$ hours failure rate & $5(15.62 \%)$ & $9(28.12 \%)$ & $14(21.84 \%)$ \\
\hline $\begin{array}{l}>\text { or equal to }<37 \text { weeks successful } \\
\text { tocolysis and preterm delivery }\end{array}$ & 12 & 11 & \\
\hline $\begin{array}{l}\text { >or equal to } 37 \text { weeks successful } \\
\text { tocolysis with term delivery }\end{array}$ & 15 & 12 & \\
\hline Success rate & $27(84.37 \%)$ & $23(71.8 \%)$ & $50(78.12 \%)$ \\
\hline
\end{tabular}

Table 4: Maternal side effects in both study groups.

\begin{tabular}{|lll|}
\hline Side effects & Nifedipine group & Isoxsuprine group \\
\hline Tachycardia $(>110 \mathrm{bpm})$ & $2(6.25 \%)$ & $3(9.37 \%)$ \\
\hline Headache & $1(3.12 \%)$ & $0(0.0 \%)$ \\
\hline Hypotension & $0(0.0 \%)$ & $5(15.62 \%)$ \\
\hline Nausea & $0(0.0 \%)$ & $0(0.0 \%)$ \\
\hline Vomiting & $0(0.0 \%)$ & $0(0.0 \%)$ \\
\hline Facial flushing & $4(12.5 \%)$ & $0(0.0 \%)$ \\
\hline
\end{tabular}

Table 5: Results of treatment in both study groups.

\begin{tabular}{|lll|}
\hline & Nifedipine group & Isoxsuprine group \\
\hline Success & $27(84.37 \%)$ & $23(71.87 \%)$ \\
\hline Failure & $5(15.62 \%)$ & $9(28.12 \%)$ \\
\hline Total & 32 & 32 \\
\hline Mean birth weight $(\mathrm{kgs})$ & 2.02 & 1.8 \\
\hline
\end{tabular}

In this study, maternal side effects were compared between two study groups. Hypotension was noted in 5 patients of isoxsuprine group as compared to nifedipine group where no patient had hypotension. While other side 
effects like headache in 1 and facial flushing noted in 4 patients of nifedipine group and tachycardia in 2 patients in nifedipine group while in 3 patients of isoxsuprine group. No other serious side effects noted in both groups (Table 4).

In this study, nifedipine has higher success rate of $84.37 \%$ compared to isoxsuprine group where $71.84 \%$ success rate. Failure rate was of $15.6 \%$ in nifedipine group, patient delivered within 48 hours of cessation of therapy and failure rate noted in isoxsuprine group is $28.12 \%$ (Table 5). Mean birth weight infant delivered in nifedipine group is $2.02 \mathrm{~kg}$ and $1.8 \mathrm{~kg}$ in isoxsuprine group (Table 5).

\section{DISCUSSION}

Determination of efficacy and safety of tocolytic agents has been a difficult task as the exact cause of preterm labor is generally not known, therefore treatment cannot be directed to a specific cause. obstetricians face the challenge managing an established preterm labor with pharmacological agents, which differ in uterine specificity, efficacy and side effects both maternal and fetal. In this study authors compared the two tocolytic drugs commonly used in India i.e. nifedipine (calcium channel blocker) and isoxsuprine hydrochloride (beta agonist).

Cochrane review on preterm labor concludes that tocolysis is definitely indicated before 34 weeks gestational age. ${ }^{10}$ This is because of reduction in number of women delivering within next 7 days and resultant decrease in neonatal morbidity from RDS, necrotizing enterocolitis, intra ventricular hemorrhage, neonatal jaundice. In this study authors found that tocolysis delayed delivery $80.64 \%$ of total cases and maximum in 28 to 34 weeks gestation age group, (Table 1) which is most susceptible group. This delay in delivery allows time for the steroids to accelerate pulmonary maturity and improve the neonatal survival.

In present study nifedipine shows significantly better result $(84.37 \%)$ in delaying delivery for 48 hours as compared to isoxsuprine only $71.87 \%$. (Table 5). Smith and Woodland compared the tocolytic effect of nifedipine with terbutaline and found similar efficacy (71\% versus $68 \%$ ) while study by Rayamajhi $\mathrm{R}$ et al and Singh N, success rate $88 \%$ versus $76 \%$ and $96 \%$ versus $75 \%$ respectively..$^{9,11,12}$

India study conducted by Singh $\mathrm{S}$ et al, observed that the prolongation of pregnancy was more when the period of gestation was less. ${ }^{13}$

The maternal side effects observed in this study were less as compared to study by Rayamajhi R et al and Singh N, where tachycardia was $23 \%$ in nifedipine group and $28 \%$ in isoxsuprine group while in this study $6.25 \%$ versus $9.37 \%$ respective study groups (Table 4). ${ }^{9,12}$ No significant change in BP was observed in nifedipine group in this study, as nifedipine exhibits greater selectively for inhibition of uterine activity relative to cardiovascular effects.

The RCOG, recommends that if tocolysis drug is to be used, Atosiban and nifedipine appear to be preferable as they have fewer side effects and seems to have comparable effectiveness. ${ }^{14}$ The "choice" of tocolysis agent, which could improve neonatal outcome with no maternal or neonatal side effect, has not yet surfaced.

\section{CONCLUSION}

The approach which prevent and treat preterm labor will have great impact on society and long-term public health care costs. Nifedipine has been found to be more favourable than isoxsuprine in this study $(84.37 \%$ versus $71.8 \%$ ) in view of increasing evidence of efficacy, safety and its ease of administration, indicating thereby that early initiation of tocolysis with nifedipine is definitely beneficial in cases of preterm labor.

Funding: No funding sources

Conflict of interest: None declared

Ethical approval: The study was approved by the Institutional Ethics Committee

\section{REFERENCES}

1. Martin JA, Kochanek KD, Strobino DM, Guyer B, MacDorman MF. Annual summary of vital statistics2003. Pediatr. 2005;115(3):619-34.

2. Begum F, Buckshee K, Pande JN. Risk factors associated with preterm labor. Bangladesh Med Ras Coune Bull. 2003;29:59-66.

3. Mishra R. Practical obstetricpProblems. In: Ian Donald $7^{\text {th }}$ edition Chapter 21; 2016:409.

4. Goldenberg R1, Chehane JF, Iams JD, Romero R. Epidemiology and causes of preterm birth. Lancet. 2008;371(9606):75-84.

5. ACOG technical bulletin. Preterm labor. Number 206-June 1995 (Replaces No. 133, October 1989). Int J Gynaecol Obstet. 1995;50(3):303-13.

6. Lyell DJ, Pullen KM, Mannan J, Chitkara U, Druzin ML, Caughey $\mathrm{AB}$, et al. Maintenance Nifedipine Tocolysis compared with Placebo. Obstel Gynecol. 2008;112:1221-6.

7. Waheed A, Shami N. Preterm labour effectiveness of transdermal glyceryltrinitrate patch. Professional Med J. 2011;18(2):174-80.

8. Royal College of Obstetrics and Gynaecologists. Tocolysis for women in preterm labour. Green-top Guideline. February 2011. No. 1b. Available at: https://www.rcog.org.uk/en/guidelines-researchservices/guidelines/ gtg $1 \mathrm{~b} /$. Accessed on $28^{\text {th }}$ March 2020.

9. Rayamajhi R, Pratap K. A comparative study between nifedipine and isoxsuprine in the 
suppression of preterm labour, Kathmandu Univ Med J. 2003;1(2):85-90.

10. King JF, Flenady VJ, Papatsonis DN, Dekker GA, Carbonne B. Calcium channel blockers for inhibiting preterm labour (Cochrane Review). The Cochrane Library; 2004:3.

11. Smith CS, Woodland MB. Clinical comparison of oral nifedipine and subcutaneous terbutaline for initial tocolysis. Am J Perinatol. 1993;10:280-4.

12. Singh N, Singh U, Seth S. Comparative study of Nifedipine and isoxsuprine as tocolytics for preterm labour. The J Obstet Gynecol India. 2011;61(5):5125.

13. Singh S, Gupta K, Ahluwalia G. Role of nifedipine in preterm labour and its effect on perinatal outcome. J Obstet Gynecol India 1992;687-693.
14. London: RCOG Press. Clinical guideline no. I (B): Tocolytic drugs for women in preterm labor. 2002. Available at: https://www.rcog.org.uk/en/guidelinesresearch-services/guidelines/ gtg1b/. Accessed on $28^{\text {th }}$ March 2020.

Cite this article as: Khoiwal S, Patidar V, Rastogi R, Tailor B. A comparative study between nifedipine and isoxsuprine in the suppression of preterm labor pain. Int J Reprod Contracept Obstet Gynecol 2020;9:2886-90. 